\title{
THE SPECIES OF THE GENUS ELYSIA FROM JAPAN
}

$\operatorname{AUTHOR}(S)$ :

Baba, Kikutaro

CITATION:

Baba, Kikutaro. THE SPECIES OF THE GENUS ELYSIA FROM JAPAN.

PUBLICATIONS OF THE SETO MARINE BIOLOGICAL LABORATORY 1957, 6(1): 69-74

ISSUE DATE:

1957-06-30

URL:

http://hdl.handle.net/2433/174573

RIGHT: 


\title{
THE SPECIES OF THE GENUS EL YSIA FROM JAPAN ${ }^{1)}$
}

\author{
KIKUTARÓ BABA \\ Biological Laboratory, Osaka Gakugei University
}

With Plates III-IV and 1 Text-figure

The following is a revised list of the species of the genus Elysia so far known from the waters around us (see also BABA 1949 and 1955). Two forms from Ryâkyú are also included in the list.

1. Elysia (Elysia) japonica Eliot, 1913

Loc.: Unknown.

2. Elysia (Elysia) yaeyamana BABA, 1936 Yaeyama-midorigai (n.n.)

Loc.: Ishigakishima, Ryûkyû.

3. Elysia (Elysia) obtusa BABA, 1938 Otome-midorigai

Loc.: Sagami Bay; Kii ; Tsuruga Bay; Toyama Bay.

4. Elysia (Elysia) babai Pruvot-Fol, $1946=$ Elysia viridis BABA, 1936 Ishigakimidorigai (n.n.)

Loc, : Ishigakishima, Ryûkyû.

5. Elysia (Elysia) trisinuata BABA, 1949 Hiramiru-midorigai

Loc.: Sagami Bay; Sugashima near Toba; Kii ; Toyama Bay.

6. Elysia (Elysia) splendens BABA, 1949 Hana-midorigai

Loc.: Sagami Bay.

7. Elysia (Elysia) hirasei BABA, 1955 Gokuraku-midorigai

Loc, : Sagami Bay.

8. Elysia (Elysia) abei BABA, 1955 Abe-midorigai

Loc.: Sagami Bay; Osaka Bay; Tsuruga Bay ; Toyama Bay ; Sado Island.

9. Elysia (Elysia) amakusana BABA, 1955 Azuki-umiushi

Loc.: Sagami Bay; Amakusa; Toyama Bay.

10. Elysia (Elysia) atroviridis BABA, 1955 Kuro-midorigai

Loc.: Sagami Bay; Suruga Bay; Sugashima near Toba; Kii ; Tsuruga

Bay; Toyama Bay; Sado Island.

11. Elysia (Elysia) livida BABA, 1955 Chigo-midorigai

Loc.: Sagami Bay; Toyama Bay.

1) Contributions from the Seto Marine Biological Laboratory, No. 293.

Publ. Seto Mar. Biol. Lab., VI (1), 1957. (Article 4) 
12. Elysia (Elysia) sugashimae BABA, 1955 Sugashima-midorigai

Loc.: Sagami Bay; Sugashima near Toba; Tsuruga Bay; Sado Island.

13. Elysia (Elysia) grandifolia KELAART, var. orientalis BABA, n.n. =Elysia grandifolia BABA, 1937 Konoha-midorigai

Loc.: Amakusa; Toyama Bay.

The following are here added to the list above.

14. Elysia (Elysia) halimedae MACNAE, 1954 Uchiwa-midorigai

15. Elysia (Elysia) hamatanii BABA, n. sp. Hamatani-midorigai (n.n.)

16. Elysia (Elysia) kushimotoensis BABA, n. sp. Kushimoto-midorigai (n.n.)

17. Elysia (Elysia) tokarensis BABA, n. sp. Tokara-midorigai (n.n.)

18. Elysia (Elysia) nigrocapitata BABA, n. n. Izumi-midorigai (n.n.)

19. Elysia (Elysia) marginata (PEASE), var. minor BABA, n. var. Hime-konohamidorigai (n.n.)

\section{Elysia (Elysia) halimedae MACNAE}

(Pl. III, Fig. 1; Pl. IV, Figs. 1a-1b)

Elysia halimedae MACnAe 1954, pp. 57-59, pl. 3, fig. 2, text-fig. 2.-S. Afr.

Animal at rest closely associated with Halimeda cuneata on which it is attached, in general shape and in colouring. Total length about $20 \mathrm{~mm}$. Parapodia much expanded, somewhat like a leaf of Halimeda, and the surface apparently smooth to the naked eyes. Rhinophores minutely papillated. The whole animal is grass-green, and it is everywhere covered with white spots which are thickest towards the outer surface of the parapodia. Upper half of the rhinophores light yellowish brown. Radula with 9 teeth in the ascending series, and 12 teeth in the descending series; each of the teeth distinctly denticulated on both edges. Spawning in early August (see BAbA 1956, p. 218).

Loc.: Wagu, Shima Province (Aug. 1951, 1 sp., coll. by the author).

\section{Elysia (Elysia) hamatanii BABA, n. sp.}

(P1. III, Fig. 2; P1. IV, Figs. 2a-2b)

Length $5-13 \mathrm{~mm}$. The black bands on the head are more accentuated than in E. hirasei BABA (see BABA 1949, pp. 34-35, 131, pl. 8, fig. 25, text-fig. 24; BABA 1955 , pp. 11, 41-42): there are 3 of these running from between the rhinophores to the anterior end of the pericardium, and an additional one immediately below the eyes on both sides. The paired rhinophores are combined by a black band across the fore end of the head. General body-colour yellowish green or grass-green, the outer surface of parapodia somewhat darker and with white spots all over, Radula 
type approximately as in hirasei: the ascending series with 10 teeth, the descending series with 13 teeth, all of these finely denticulated. This species is regarded as new to science.

Loc.: Seto, Kii (Jan. 1951, 2 sps., coll. by Mr. HamatanI; Dec. 1955, many sps., coll. by the author).

\section{Elysia (Elysia) kushimotoensis BABA, n. sp.}

(Pl. III, Fig. 3; Pl. IV, Figs. 3a-3b)

Length about $30 \mathrm{~mm}$. Ground-colour yellowish green, the head brownish, the parapodial surface more darker, almost chocolate brown, and conspicuously maculated with white; the whole body scattered with additional orange-red spots. Parapodial margin with a double border, the outer black and the inner orange-red. Rhinophores brownish to the tip. Radula with 7 teeth in the ascending series, 7 teeth in the descending series, and a heap of these in the ascus. All the teeth finely denticulated.

Loc.: Kushimoto, Kii (Aug. 1951, 1 sp., coll. by Mr. HAMATANI).

\section{Elysia (Elysia) tokarensis BABA, n. sp.}

(Fig. 1 ; Pl. IV, Figs. 4a-4b)

Somewhat allied to E. yaeyamana in general colouring, but distinct from it in having black spots on parapodia, and in the shape of the radula teeth. Length of animal about $15 \mathrm{~mm}$. Ground-colour yellowish green (or bluish green), the parapodial margin ashy white or almost purplish black, and with a submarginal chrome-yellow line. White spots as usual scattered on parapodial surface. Rhinophores faintly black at extreme tip, and with a chrome-yellow band about halfway down. Radula with 5 teeth in the ascending series, 7 teeth in the descending series, and a heap of these in the ascus. Each tooth finely denticulated at edge.

Loc.: Takarajima of Tokara group, southern Kyûshû (May 1953, 3 sps., coll. by the author).

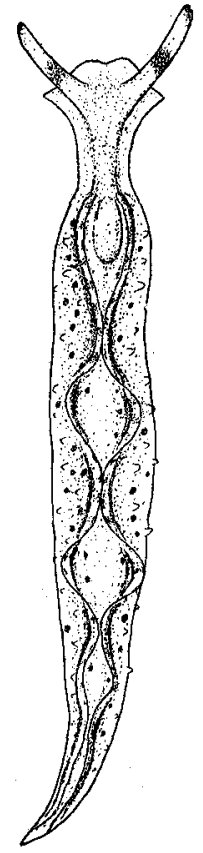

Fig. 1. Elysia tokarensis (Takarajima, May 26, 1953, total length 15 $\mathrm{mm}$ ).

\section{Elysia (Elysia) nigrocapitata BABA n. n.}

(Pl. III, Fig. 4 ; Pl. IV, Figs. 5a-5b)

Elysia (Elysia) viridis BABA 1947, p. 1077, fig. 3050 (non text).

About $5 \mathrm{~mm}$ in length. Head black excepting round the eyes. General body-colour 
yellowish green, becoming darker towards the outer surface of the parapodia, and to the tip of the tail. The parapodial margin white. Radula with 10 teeth in the ascending series, 12 teeth in the descending series, and a heap of these in the ascus. All the teeth very finely denticulated. The black head especially characterizes the species.

Loc.: Tannowa, Osaka Bay (Nov. 1950 and Dec. 1952, several sps., coll. by Mr. Hamatani); Seto, Kii (Dec. 1955, 1 sp., coll. by the author); Myojinzaki Mizushima, Tsuruga Bay (July 1956, 1 sp., coll. by Mr. ABE); Abugashima, Toyama Bay (Aug. 1953, 1 sp., coll. by Mr. ABE) ; Amaharashi, Toyama Bay (Dec. 1955 and Aug. 1956, many sps., coll. by $\mathrm{Mr}$. ABE).

Elysia (Elysia) marginata (PEASE), var. minor BABA, n. var.

(Pl. III, Fig. 5 ; P1. IV, Figs. 6a-6b)

The two species, E. grandifolia KelaART and E. marginata (PEASE), are much alike in general body-form and in colouring. But it is generally noted that the radula teeth of the former are denticulated and those of the latter non-denticulated. Our specimens which will be described below have obviously the radula type of the latter species. They appear, however, to be distinguished from the typical marginata by the smaller size of body and by the narrower parapodia having 3 natural undulations on the edge.

Length usually $12-17 \mathrm{~mm}$, at most $40 \mathrm{~mm}$. General ground-colour yellowish green, the whole outer surface of body including the sole rather thickly spotted with black. With additional white spots all over as usual. Parapodia with a double border, the outer black and the inner orange-red. The rhinophores orange-red towards the tip, their auriculate margin black. The tip of the tail not black. Radula usually. with 5 teeth in the ascending series, 7-10 teeth in the descending series, and a heap of these in the ascus. No denticulations found on edge of teeth. All of our specimens are tentatively regarded as forming a new variety of the typical marginata.

Loc.: Seto, Kii (Aug. 1952, 2 sps., coll. by Messrs. Yamamoto, Hamatani and Hisal); off Sajima, Sagami Bay, $11 \mathrm{~m}$ (Aug. 1940, 1 sp., coll. by His Majesty's Biol. Lab.) ; Myojinzaki Mizushima, Tsuruga Bay (July 1956, 1 sp., coll. by Mr. ABE); Abugashima, Toyama Bay (July 1953, 2 sps., coll. by Mr. ABE).

\section{Additional notes}

1. Elysia (Elysia) grandifolia KeLAART, var. orientalis BABA, n. n. This agrees with the typical grandifolia from the Indian Ocean (1) in colours, (2) in the exceedingly wide parapodia and (3) in the serrulated radula teeth, but appears to differ from it (1) in the shorter radula ribbon and (2) in the acutely pointed blade of each of the teeth (cf. O'Donoghue 1932). 
2. Elysia (Elysia) sugashimae BABA (Pl. III, Fig. 6; Pl. IV, Figs. 7a-7b). The animal taken from Sugashima near Toba measures about $25 \mathrm{~mm}$ in length. General ground-colour grass-green, the whole upper surface of body covered with scattered orange-red spots, interspersed with white ones. Tip of rhinophores black. Radula with 7 teeth in the ascending series and 10 teeth in the descending series. Teeth unciform (see also BABA 1955).

\section{LITERATURE}

BABA, K. 1936. Opisthobranchia of the Ryâkyû (Okinawa) Islands. Journ. Dept. Agric. Kyûshû Imp. Univ., vol. 5, no. 1. no. 4 . 1937. Opisthobranchia of Japan (I). Journ. Dept. Agric. Kyûshû Imp. Univ., vol. 5,

1938. Opisthobranchia of Kii, Middle Japan. Journ. Dept. Agric. Kyûshû Imp. Univ., vol. 6 , no. 1 .

1947. Dôbutsu Zukan (Illustrated encyclopedia of the fauna of Japan), revised edition. Mollusca.

1949. Opisthobranchia of Sagami Bay. Iwanami Shoten, Tôkyô.

1955. Opisthobranchia of Sagami Bay. Supplement. Iwanami Shoten, Tôkyô.

BABA, K., Iw. HAMATANi and K. HiSAI 1956. Observations on the spawning habits of some of the Japanese Opisthobranchia (II). Publ. Seto Mar. Biol. Lab., vol. 5, no. 2.

ElioT, C. 1913. Japanese nudibranchs. Journ. Coll. Sci. Imp. Univ. Tôkyô, vol. 35, art. 1.

Macnae, W. 1954. On four sacoglossan molluscs new to South Africa. Ann. Natal Mus., vol. 13, pt. 1.

O'Donoghue, C. H. 1932. Notes on Nudibranchiata from Southern India. Proc. Malac. Soc. London, vol. 20 , pt. 3.

Pruvot-Fol, A. 1946. Révision critique de la famille des Elysiadae. Journ. de Conchyliol., vol. 87 , no. 1 .

1947. Post scriptum a la révision critique de la famille des Elysiadae. Journ. de Conchyliol., vol. 87 , no. 3 . 


\section{EXPLANATION OF PLATES III-IV}

Plate III

Fig. 1. Elysia halimedae (Wagu, Shima Province, Aug. 2, 1951, length $20 \mathrm{~mm}$ ).

Fig. 2. Elysia hamatanii (Seto, Jan. 4, 1951, length $10 \mathrm{~mm}$ ).

Fig. 3. Elysia kushimotoensis (Kushimoto, Kii, Aug. 7, 1951, length $30 \mathrm{~mm}$ ).

Fig. 4. Elysia nigrocapitata (Tannowa, Osaka Bay, Nov. 23, 1950, length $5 \mathrm{~mm}$ ).

Fig. 5. Elysia marginata, var. minor (Seto, Aug. 5, 1952, length $12 \mathrm{~mm}$ ).

Fig. 6. Elysia sugashimae (Sugashima, July 8, 1952, length $25 \mathrm{~mm}$ ).

\section{Plate IV}

Figs. 1a-1b. Elysia halimedae.

1a. Radula teeth $(\times 100)$; 1b. A tooth $(\times 160)$.

Figs. 2a-2b. Elysia hamatanii.

2a. Radula teeth $(\times 120)$; 2b. A tooth $(\times 310)$.

Figs. 3a-3b. Elysia kushimotoensis.

3a. Radula teeth $(\times 120)$; 3b. A tooth $(\times 160)$.

Figs. 4a-4b. Elysia tokarensis.

4a. Radula teeth $(\times 160)$; 4b. A tooth $(\times 240)$.

Figs. 5a-5b. Elysia nigrocapitata.

5a. Radula teeth $(\times 310)$; 5b. A tooth $(\times 620)$.

Figs. 6a-6b. Elysia marginata, var. minor.

6a. Radula teeth $(\times 220)$; 6b. A tooth $(\times 310)$.

Figs. 7a-7b. Elysia sugashimae.

7 a. Radula teeth $(\times 22)$; $7 \mathrm{~b}$, A tooth $(\times 70)$. 
Publ. Seto Mar. Biol. Lab., VI, 1 (1957)

PLATE III
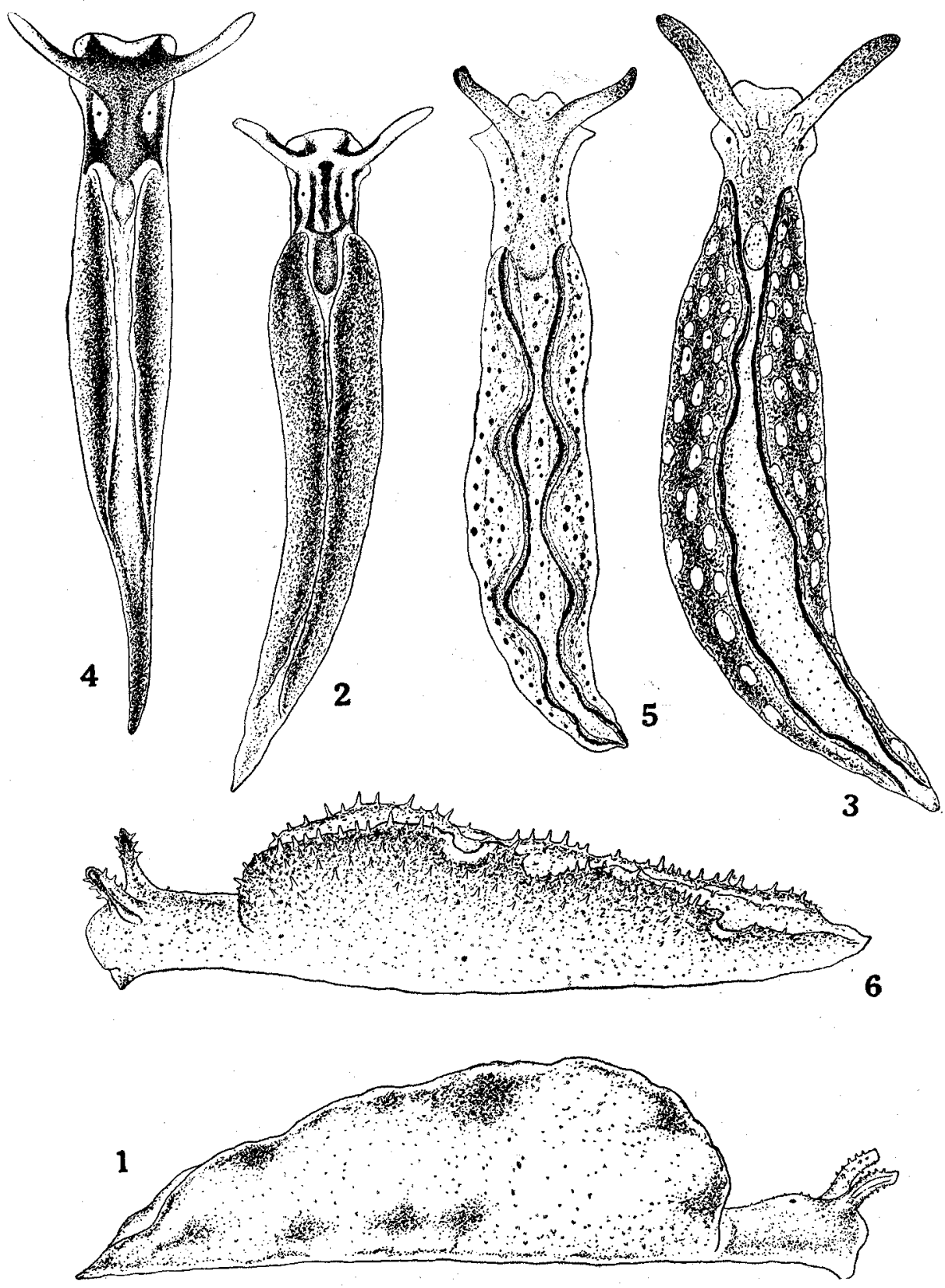

K. BABA: The Species of Elysia from Japan. 
Publ. Seto Mar. Biol. Lab., VI, 1 (1957)
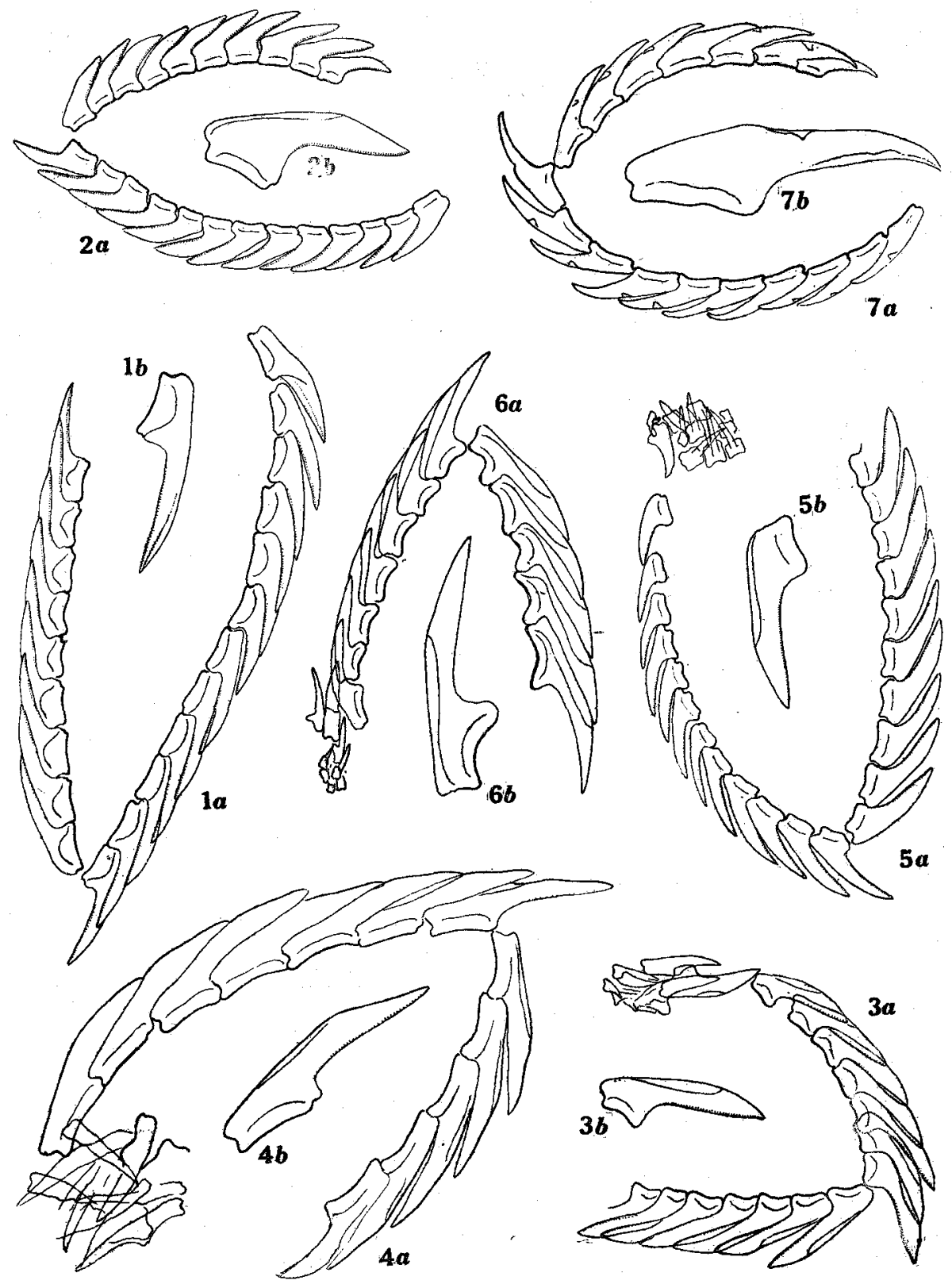

K. Baba: The Species of Elysia from Japan. 